\title{
Construction of the financial inclusion agenda in light of the actor-network theory
}

\author{
Vilma Meurer Sela ${ }^{1}$ \\ Lauro Gonzalez ${ }^{2}$ \\ Tania P. Christopoulos ${ }^{3}$ \\ 1 Universidade Estadual de Maringá / Departamento de Administração, Maringá / PR - Brazil \\ 2 Fundação Getulio Vargas / Escola de Administração de Empresas de São Paulo, São Paulo / SP - Brazil \\ ${ }^{3}$ Universidade de São Paulo / Escola de Artes, Ciências e Humanidades, São Paulo / SP - Brazil
}

\begin{abstract}
This article adopts the perspective of the actor-network theory to understand the role of the actors in the process of social construction of the financial inclusion agenda, considering that agenda-setting can be seen as a continuous process of associations that involves different mediators. Data were collected through semi-structured interviews with representatives of the institutions involved in the process of agenda-setting examined, as well as from documentary sources. The dynamics of the process of developing the financial inclusion agenda were analyzed considering the four moments (problematization, interessement, enrolment, and mobilization) presented in the relevant literature. The research found out that the financial inclusion agenda in Brazil is the result of an incremental process, which was attended by a wide range of actors (government, market, developers and scholars, and also international actors) and it was influenced by some non-human elements, among which the Central Bank of Brazil (BCB) stands out as the focal actor of the process.
\end{abstract}

Keywords: agenda-setting; financial inclusion; actors; financial inclusion agenda.

\section{Construção da agenda de inclusão financeira à luz da Teoria Ator-Rede}

Este artigo procurou compreender a atuação dos atores no processo de construção social da agenda de inclusão financeira no Brasil, utilizando a Teoria Ator-Rede (TAR) como lente teórica, visto que a formação da agenda pode ser compreendida como um contínuo processo de associações que envolve diferentes mediadores. Os dados foram coletados por meio de entrevistas semiestruturadas com representantes das instituições envolvidas no processo de construção da agenda em tela, bem como de fontes documentais. A dinâmica do processo de construção da agenda de inclusão financeira foi analisada considerando os quatro momentos da translação (problematização, atração de interesses, recrutamento e mobilização) apresentados na literatura pertinente. Verificou-se que a agenda de inclusão financeira no Brasil é fruto de um processo incremental, que contou com a atuação de uma ampla gama de atores (do governo, do mercado, fomentadores e estudiosos e internacionais) e que foi influenciada por alguns elementos não humanos, destacando-se o Banco Central do Brasil (BCB) como ator focal do processo.

Palavras-chave: formação da agenda; inclusão financeira; atores; agenda de inclusão financeira.

\section{Construcción de la agenda de inclusión financiera a la luz de la teoría actor-red}

Este artículo se propuso comprender el papel de los actores en el proceso de construcción social de la agenda de inclusión financiera en Brasil, utilizando la teoría del actor-red (TAR) como lente teórica, ya que la formación de la agenda puede entenderse como un proceso continuo de asociaciones que involucra a diferentes mediadores. Los datos se recolectaron a través de entrevistas semiestructuradas con representantes de las instituciones involucradas en el proceso de construcción de la agenda en cuestión, así como de fuentes documentales. Se analizó la dinámica del proceso de construcción de la agenda de inclusión financiera considerando los cuatro momentos de la traducción (problematización, participación, enrolamiento y movilización) presentados en la literatura relevante. Se comprobó que la agenda de inclusión financiera en Brasil es el resultado de un proceso incremental, al que asistieron una amplia gama de actores (gobierno, mercado, desarrolladores y académicos, así como internacionales) y que fue influenciada por algunos elementos no humanos, entre los que se destaca el Banco Central do Brasil (BCB) como el actor central del proceso.

Palabras clave: formación de la agenda; inclusión financiera; actores; agenda de inclusión financiera. 


\section{INTRODUCTION}

This research sought to understand the role of the actors in the process of social construction of the financial inclusion agenda in Brazil. Such agenda is the first step in the governments' decisionmaking process (Baumgartner \& Jones, 1993), and it involves identifying the problem, introducing the topic (problem) within the agenda and selecting alternatives to solve it (Kingdon, 1995). This pre decision-making stage is characterized by the confrontation of ideas and interests aiming to identify and choose alternatives and political solutions.

Financial inclusion is a topic that has been increasingly discussed not only in Brazil, but also all over the world. That is notably due to its role in fostering economic and social development by promoting the inclusion of low-income population into financial services market areas, such as a) credit; b) insurance; and c) savings. Demirgüç-Kunt, Klapper, Singer, Ansar and Hess (2018) suggest that financial services contribute to fighting poverty as they ease the management of financial resources related to healthcare, education, businesses and emergencies, such as job loss or illnesses. Gonzalez and Moser (2015) analyze the importance of financial inclusion through credit as a way of dealing with the challenges imposed by climate changes.

On the other hand, it is necessary to consider the negative effects of financial inclusion, among which over-indebtedness stands out (Afonso, Morvant-Roux, \& Guérin, 2017; Schicks, 2014). It is often a result of inability to manage financial resources which become accessible (Altman, 2012; Custers, 2011). Cull and Morduch (2017), in their turn, evaluate microfinances as a mechanism which mitigates cyclical problems or punctual lack of resources. However, according to the authors, they are not capable of changing low-income reality substantially. Similarly, Banerjee, Karlan, and Zinman (2015) discuss evidences regarding lack of impact of microcredit programs on poverty reduction.

It is important to stress the role of financial education in this context. In a study involving riverside population, Santos and Joia (2018) highlight that lack of basic education has been an obstacle to the adequate use of available financial services, thus hindering sustainable financial inclusion. Appropriate financial education levels could contribute to reducing indebtedness levels among the population (Kunkel, Vieira, \& Potrich, 2015; Minella, Bertosso, Pauli, \& Corte, 2017) considering ethical issues attached to financial education, especially regarding the characteristics of products offered by the financial system (Leandro \& Gonzalez, 2018).

Having in mind these controversies, in this study we tried to understand the process of social construction of the financial inclusion agenda by analyzing the characteristics of the actors involved, the organizations they represent, the resources they have at their disposal, the roles they play, the interests and ideas they stand up for, the relationships among them, as well as the identification and understanding of the factors that influence their decisions. Through this perspective, this study was guided by the Actor-Network Theory (ANT), since the agenda-setting can be understood as a continuous process of associations which involve different mediators.

Therefore, this research was based on the assumption that policies are a result of articulation among the actors, as well as their interaction with several factors (non-human elements) which shape their role in the decision-making process. Public policies reflect the ideas of the actors or distinct groups, and they result from political exchanges established among these actors at specific moments of the political scenario. In addition, the actors' decisions are shaped by a microenvironment which surrounds them. 
By analyzing the actors' role in the financial agenda-setting, this research contributes not only to presenting the trajectory of the social construction of the financial inclusion agenda, but also to understanding the connection among the actors, as well as identifying the elements which had influence on them during the decision-making process.

Through that perspective, this study is justified not only due to the controversial discussions that financial inclusion has caused in the last few decades, but also because it focuses on more subject aspects that interfere in the process of developing a public agenda, and which were analyzed through the ANT. Besides this introductory section, this paper is divided into other 4 sections that present: a) the construction process in light of the ANT; b) the methodological aspects of our research; c) the analysis of the social construction of the financial inclusion agenda; d) final considerations.

\section{CONSTRUCTION OF THE AGENDA IN LIGHT OF THE ACTOR-NETWORK THEORY}

The process of building a government's agenda (how it is established and which topics must be covered) involves analyzing the participation of different actors (who takes part and how they do) (Cobb \& Elder, 1971). The models for analyzing the agenda-setting presented by Baumgartner and Jones (1993) and Kingdon (1995) also address the participation of actors in the process which is influenced by political, institutional, structural and other factors. Both models devote their attention to the dynamics of ideas in the political process. According to Kingdon's (1995) model, the political arena (politics) is an element that has influence over the governmental agenda. The model proposed by Baumgartner and Jones (1993), in its turn, considers that the institutional context influences the process of defining problems and solutions. In that sense, the process of agenda-setting is seen as a pre-decision making stage in the cycle of public politics, which involves identifying the problem, introducing the topic within the agenda and selecting alternatives.

Kingdon (1995) emphasizes that the role of the actors who invest their resources and (economic, political and knowledge-related) power in order to favor the objects of those public policies they stand up for is present in the three streams of his model (problems, policies and politics). According to the author, the actors usually make use of power and equity as criteria to guide the development of alternative proposals and solutions in terms of policies. Thus, their ideas and interests become a reference to the following stage of the public policies cycle, which is developing a policy. It is important to highlight that, in all the three streams, the actors are in a constant process of reaching consensuses and, in that sense, arguments, persuasion and reason are pivotal elements.

Through this perspective, the ANT bas been used in the studies on public policies in several fields (Andrade, 2006; Fornazin \& Joia, 2015; Jerković \& Petak, 2017; Pinto \& Domenico, 2014; Ramos, 2009) for it provides understanding on the process of public policies as a collective construction, which integrates different actors (individuals and groups, governmental or non-governmental) who interact and are influenced by several structural or relational factors. Thus, this theory can be used as a theoretical lens to analyze the process of agenda-setting, which is understood as a continuous process of association among different actors in a way that none of them prevails, but the whole network does. Therefore, it knocks down the assumption according to which governments are absolute and central protagonists when it comes to solving public problems (Andrade, 2006). These associations involve different mediators that are seen by the ANT as entities that are neither pure humans nor pure nonhumans, and which are named actants. That being said, the ANT approach is useful when it comes 
to understanding the trajectory of the agenda by emphasizing the interrelated and heterogeneous character of their actants, either social or natural.

In such approach, it is important not to prioritize any of the actors in advance. Instead, it is necessary to monitor the formation of a heterogeneous network of actants step by step, paying attention to the effects that result from the actions of each of them. The idea, rather than privileging acting or structure (humans or hon-humans), is carrying on the analysis free from predetermined notions in the research process (Alcadipani \& Tureta, 2009).

Through the approach offered by the ANT, it is possible to follow the actors by mapping the network connections, outlining the relations established among the several actants and the knots that compose the network (Callon, 1986; Latour, 2012). That enables us to pay attention to the way they are interlaced with the elements that influence their acting because, according to the ANT, nonhuman elements also play a role and, thus, they may authorize, permit, suggest, influence and forbid (Camillis, Bussalar, \& Antonello, 2016).

According to the ANT, the truth is not something external to be discovered. Instead, it is a collective construction (Fornazin \& Joia, 2015). In that sense, in order to analyze the role played by the actors in the process of financial inclusion agenda-setting, we must take the interactions that happen through the mediation among them as the object of study. Based on this approach, we can not only describe the bonds and alliances that are created, but also, and above all, carry out the analysis of the effects caused by such bonds (Latour, 1999). It is possible to understand the negotiations, displacements and transformations caused by the action of several actors.

In light of the foregoing, agenda-setting is a dynamic process, in which the actors connect in a way that they transport sense and meanings, taking part as intermediaries and mediators. This dynamics can be analyzed through translation (Callon, 1986), a process through which different actors share a common goal and build a relationship network in order to achieve that goal. Translation can be understood as the mobilization of actors around a common goal, which is named obligatory passage point (OPP). The OPP establishes the connection within the actors network (Callon, 1986). The translation process is composed of 4 moments summarized in Figure 1.

\section{FIGURE 1 TRANSLATION MOMENTS}

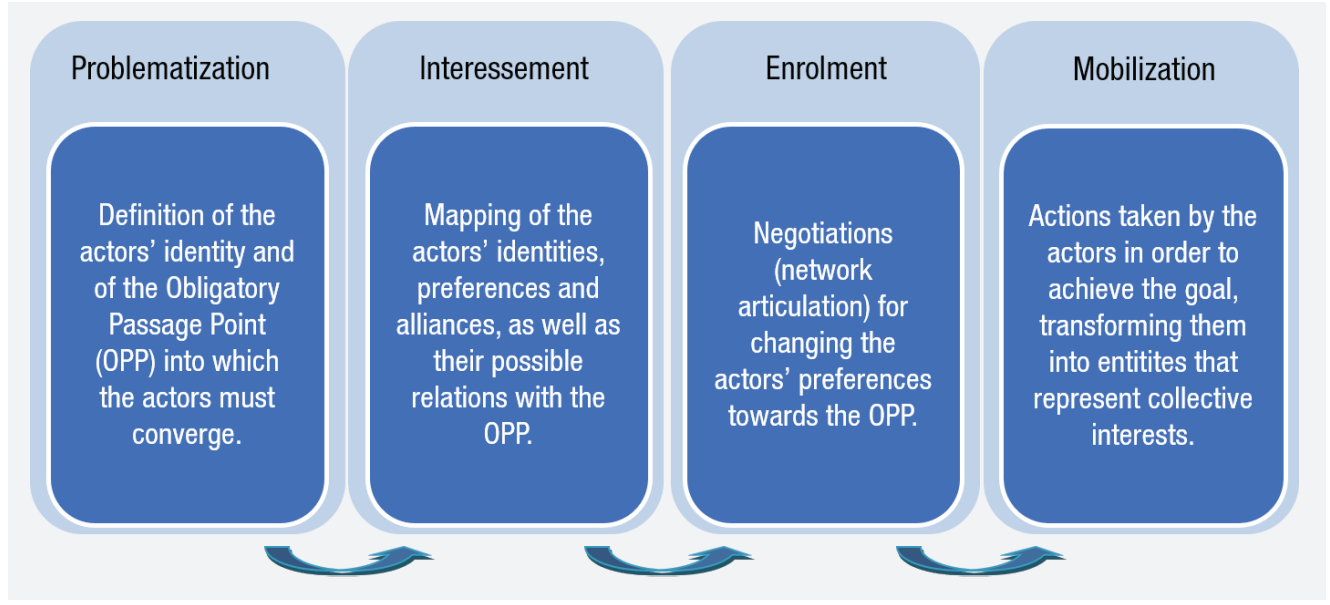

Source: Elaborated by the authors. 
The first moment (problematization) is characterized by the definition of the actors' identity and the OPP. Their identities are defined as other actors convince them that they share the same goal, thus, forging alliances. As they recognize the need of the goal, as well as the importance of the alliance in order to achieve it, they acknowledge that the proposal made by the actor or group of actors they were convinced by is an obligatory passage point, without which it would not be possible to get where they want to. At the second moment (interessement), the goal is a change in the actors' identities by using mechanisms which can be placed among them. Such mechanisms may weaken or terminate unwanted relationships among the actors, besides creating other wanted relationships. At the third moment (enrolment), members start being resistant and, thus, the network is questioned: in what conditions and at what levels (how, how much, when, where) do the actors agree on negotiating in order to adhere to the division of tasks and definition of roles and, then, become allies? During the process, these levels are revealed and negotiations take place between the OPP and the actors involved. Finally, comes the fourth moment (mobilization), which means that the actors gradually surrender to the propositions presented by those who are the temporary leaders in the network. It happens gradually, as they surrender to the intermediaries who represent them, until the moment that the latter agree to delegating their interests towards a single representative.

Translation takes place when the actors go through these four stages and change their preferences towards an OPP, thus achieving a moment of temporary stability. Stability of the network leads the structure to turning into what Latour (2001) names "black box", that is, a frozen element of the network, with "irreversibility properties". The translation processes lead to a constant threaten of social disruptions and the creation of ways of organizing the resources and the relations in the actors network (Luhmann, Bednarz, \& Baecker, 1996). Therefore, strategies are developed in order to control resistance to the order that has been established, forming a relatively stable system in the translation process.

\section{METHODOLOGICAL PROCEDURES}

This study was guided by qualitative research procedures (Godoy, 1995) and was carried out through an ex post facto investigation (Cooper \& Schindler, 2003) of longitudinal perspective, for it seeks to understand the movement and creation of groups or networks, as well as the translations (Fornazin \& Joia, 2015) within the process of social construction of the financial inclusion agenda.

This research relied on two sources of evidence, namely a) primary data, which comprises interviews with representatives of the institutions involved in the process of agenda-setting through different temporal and spatial perspectives; and b) secondary data: documental sources, which allowed us to confirm the facts that were brought to light by the interviews.

The interviews were done with key-actors who participated in the process of developing the Brazilian financial inclusion agenda. Interviewees were chosen by using a technique called Snowball Sampling. It consists in selecting a non-probabilistic sample in which the first participants nominate the others until the proposed goal is achieved (Atkinson \& Flint, 2001). The first group selected included actors from the government, market, as well as scholars and promoters (development agents), who helped create the book called Financial Inclusion Project: perspectives and challenges for financial inclusion in Brazil: the viewpoint of different actors, organized by Feltrim, Ventura, and Dodl (2009). 
The second group of interviewees encompassed the actors who were mentioned by the interviewees from the first group. The interviews of both the first and second groups took place simultaneously, depending on interviewees' availability. As prescribed by the Snowball Sampling technique, the search for new interviewees finished when the names and discourses started being repeated, which is called saturation.

The participants were interviewed on the phone or Skype, from October to December, 2016. The interviews were recorded (with the interviewees' permission) and, then, transcribed by using Google Docs. We created codes in order to not reveal the interviewees' identity (Box 1). The codes consist of letters, which represent the category to which the interviewees belong (GA = Government Actors; MA = Market actors; PS = Promoters and Scholars), and numbers, which stand for the order of the interviews within each category.

\section{BOX $1 \quad$ LIST OF INTERVIEWEES}

\begin{tabular}{|c|c|}
\hline Interviewees & Institution \\
\hline GA-01, GA-02, GA-03, GA-10, GA-12 & Central Bank of Brazil (BCB) \\
\hline MA-01 & $\begin{array}{l}\text { National Association for the Co-operative Movement of Credit in Family Solidarity } \\
\qquad \text { Economics (Ancosol) }\end{array}$ \\
\hline PS-01 & Institute of Work and Society Studies (IETS) \\
\hline $\mathrm{GA}-04, \mathrm{GA}-13$ & Ministry of Labor and Employment (MTE) \\
\hline GA-05 & Brazilian Development Bank (BNDES) \\
\hline GA-07 & Ministry of Agrarian Development (MDA) \\
\hline MA-02 & Organization of Brazilian Cooperatives (OCB) \\
\hline GA-06, GA-08 & Ministry of Finance / Chief of Staff \\
\hline GA-09 & Ministry of Education and Culture (MEC) \\
\hline MA-03 & Brazilian Association of Microcredit and Microfinances Entities (ABCRED) \\
\hline GA-11 & National Department of Solidarity Economics (SENAES) \\
\hline PS-02 & Brazilian Micro and Small Enterprises Support Service (SEBRAE) \\
\hline PS-03 & Institute of Applied Economics Research (IPEA) \\
\hline
\end{tabular}

Source: Elaborated by the authors.

It was not possible to interview all the actors we got in touch with for some of them were not available for different reasons. For more than once, we tried to contact 4 government actors, 6 market actors, 2 scholars and 2 international actors with no success, which means 14 interviews that did not happen.

The interviews questionnaire comprised questions on 3 topics related to the object of study: a) actors identification; b) articulation among them; and c) interaction of the actors who had influence on the agenda-setting process. The first set of questions aimed to find out why financial inclusion 
had become part of the interviewees' agenda, thus becoming an OPP, besides getting to learn about the interaction among human and non-human actors. The second set aimed to verify if there was cooperation or competition during the process, in order to characterize the interessement stages. The aim of the last set of questions was identifying the elements which contributed to consolidating the agenda, as well as identifying the actants who spoke on behalf of all the other actors.

The secondary data (Box 2) helped us understand the historical process of the agenda-setting in question, as well as confirm the interviewees' discourse (triangulation).

\section{BOX $2 \quad$ LIST OF DOCUMENTS ANALYZED}

$\begin{array}{ll}\text { Annals } & \text { I and II Forums on Financial Inclusion. } \\ \text { Laws } & \text { Law number 9.790, March 23th, 1999; } \\ & \text { Law number 10.194, February 14th, 2001; } \\ & \text { Law numer 11.110, April 25th, 2005. } \\ & \text { Financial Inclusion Project - perspectives and challenges for financial inclusion in Brazil: the } \\ & \text { viewpoint of different actors (2009); } \\ \text { Documents } & \text { Action Plan for Strengthening Institutional Environment (2012); } \\ & \text { Financial Inclusion Reports (RIF) I (2010), RIF II (2011) and RIF III (2015); } \\ & \text { Report on the National Partnership for Financial Inclusion (PNIF) 2012-2014. } \\ & \text { Alliance for Financial Inclusion (AFI); } \\ \text { Central Bank of Brazil (BCB); } & \text { Brazilian Development Bank (BNDES); } \\ \text { Center for Financial Inclusion (CFI); } & \text { Group of } 20 \text { (G20); } \\ & \text { Ministry of Labor and Employment (MTE); } \\ & \text { World Bank. }\end{array}$

Source: Elaborated by the authors.

The data were dealt with through content analysis (Bardin, 1979), which aims at the treatment of the content available through written documents, as well as other forms of expression, such as spoken discourse, images, maps and symbols. Our research relied on the use of the software Atlas TI for codifying the analysis categories and help with data systematization. Since the ANT does not assume the possibility of predicting prior structures or categories, the analysis categories were outlined after data collection and also after a preliminary reading of the content from the interviews transcribed. Once the categories were created with the aid of the aforementioned software, data were extracted and, then, systematized within categories to be analyzed.

After these steps, we sought a historical reconstruction of the discussions on financial inclusion, which suits an ANT-based analysis, focusing on articulations among the actors, as well as their interaction with the elements that influenced their decisions. Figure 2 presents the methodological design of the research. 
Goal

Understanding the role played by the actors in the process of social construction of the financial inclusion agenda in Brazil.

\begin{tabular}{|lll|}
$\begin{array}{ll}\text { Data } \\
\text { collection }\end{array}$ & $\begin{array}{l}\text { Examining documents } \\
\text { which } \\
\text { are relevant } \\
\text { to the study. }\end{array}$ & $\begin{array}{l}\text { Semi-structured interviews with key-actors: } \\
\text { Creating the script/questionnaire, based on goals and } \\
\text { theoretical lens; } \\
\text { Applying the script and selecting interviewees through } \\
\text { the snowball sampling technique - from October to } \\
\text { December 2016. }\end{array}$ \\
\hline Data triangulation & It confirmed the data provided by the interviews taking into account \\
& the documents examined.
\end{tabular}

Analysis

Content analysis (Bardin, 1979); categories defined a posteriori.

Historical reconstruction of the discussions on financial inclusion, in a way that suits an ANT-based analysis, focusing on the articulation among the actors, as well as on their interaction with the elements that influenced their decisions.

Source: Elaborated by the authors

\section{ANALYSIS OF THE FINANCIAL INCLUSION AGENDA-SETTING}

This section presents the historical reconstruction of the financial inclusion agenda-setting in Brazil through the four translation moments (Callon, 1986). First of all, it presents a preamble of the agenda and the (human) actors who took part in the formation process. Then, it presents the translation moments in a brief discussion on the (non-human) elements which had influence over the role played by the actors.

The financial inclusion agenda in Brazil went through a process of concepts evolution - microcredit, microfinances, financial inclusion and financial citizenship. At first, it focused on microcredit, which was initially offered through non-governmental organizations in the 1970's until 2003.

Later, through a gradually wider view, the agenda started being addressed as microfinances, which, besides credit, encompassed access to means of payment, savings and insurance. In 2009, it was conceived as financial inclusion, trying to provide the population with effective access and use 
of financial services suitable to their needs. The population was then incorporated by microfinances services through consumers and financial education. Within this conception, financial inclusion became one of the pillars that, together with financial education and consumer protection, composed in 2015 a new agenda: financial citizenship. That was a concept related to citizens' rights and duties when it comes to financial life. In that scenario, the agenda aims to provide citizens with financial protection, education and inclusion.

The agenda chronology corresponds to the days when the following events were promoted by the Central Bank of Brazil (BCB): a) microcredit seminars, up to 2003; b) microfinances seminar, from 2003 to 2008; c) forums on financial inclusion, from 2009 to 2014; and d) yearly forums on financial citizenship, since 2015.

Therefore, the Brazilian financial inclusion agenda was an incremental process because

It was not something stationary, things started happening and trends were just showing up and justifying their path (GA-03).

Before developing into microcredit, the agenda started being built due to the Solidary Community Program by Ruth Cardoso, who initially supported measures towards institutional strengthening and qualification of the information system (PS-02). The agenda was built throughout the years, especially with the forums. At first, they addressed microcredit and microfinances. Later, in 2008, they were named as Forum on Financial Inclusion. Therefore, financial inclusion gradually gained prominence due to the debates promoted by the forums, as well as the measures and programs implemented over the years, which are the result of articulation among those who acted in support of this agenda.

BOX 3 ACTORS IN THE FINANCIAL INCLUSION AGENDA-SETTING

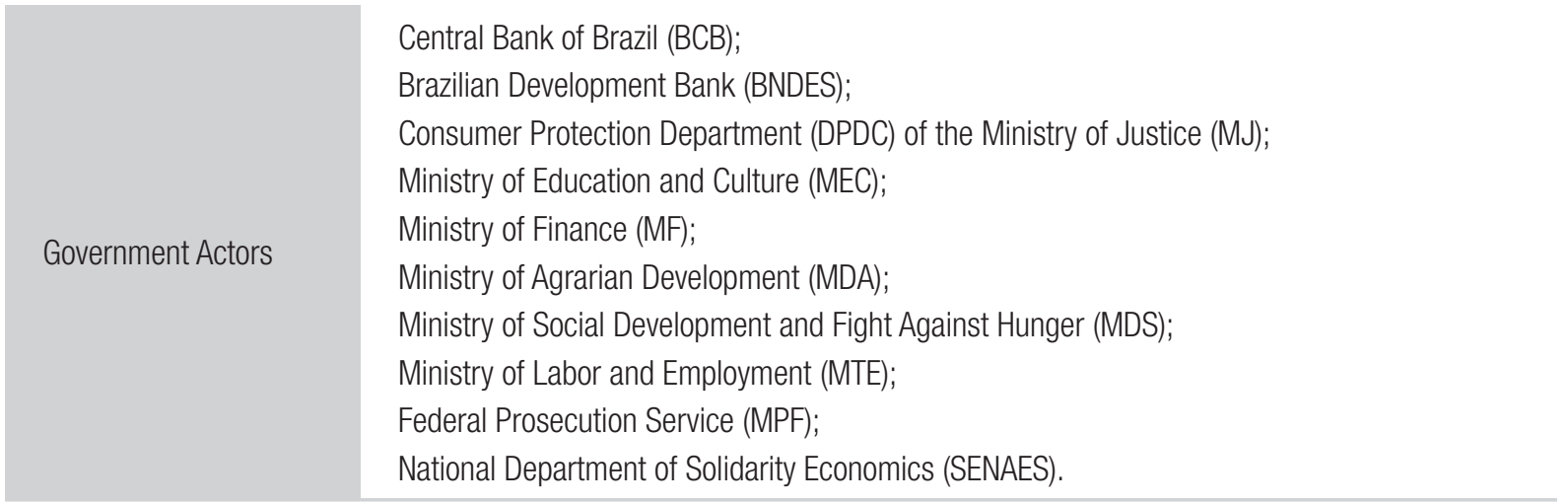




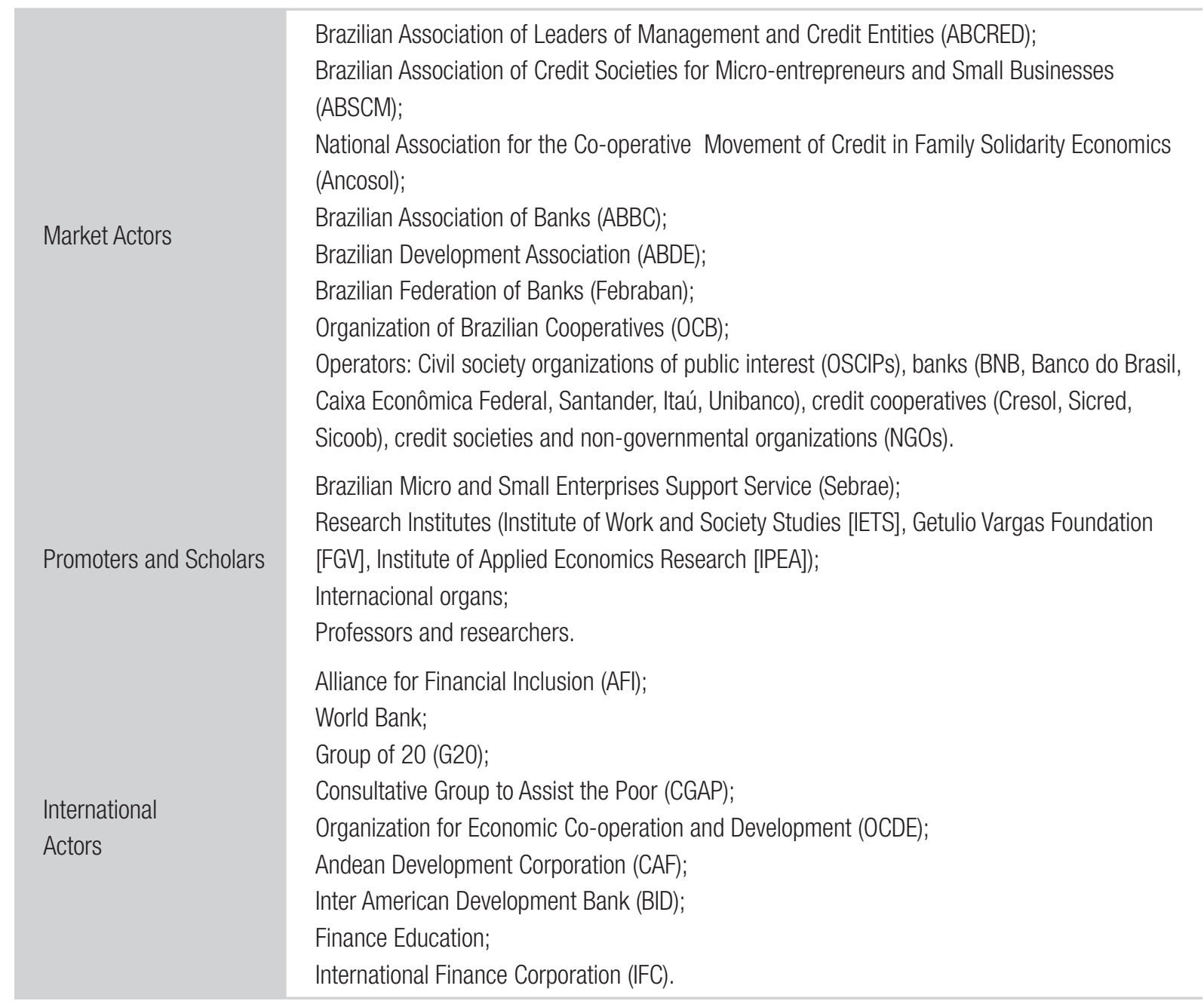

Source: Elaborated by the authors.

The actors were identified mainly through material published on the theme, available on the $\mathrm{BCB}$ website. The interviews endorsed the publications and also enabled identifying the actors and moments that led to constructing the agenda, which is presented from now on, considering the four translation moments.

\subsection{Problematization}

GA-03 reports that during the 2008 seminar, the actors realized they had already achieved the goals of widely disclosing the measures related to microfinances. Therefore, they needed to reformat the theme. According to the interview, at that time, the Norms and Organization Director of the BCB Financial System stated that microfinances rounds were over. Then, the actors started thinking about what could have been done differently, since the issue encompassed much more than just microfinances. GA-03 states that other topics, such as qualification and governance, among others, should be included.

GA-10 says "I still didn't have in mind the term financial inclusion", but there was "this priority that should be met". Then, GA-10 started communicating with their interlocutors acknowledging that the 
$\mathrm{BCB}$, financial institutions, as well as other actors, should become partners, but in a way that their constitutional or regimental competence would not be affected.

Through GA-10's viewpoint, each agent played a regimental role, and that should be articulated. According to that perspective, the then president of the $\mathrm{BCB}$ defended the need of connection among the whole network and all its public and private actors in order to speed up the process of financial inclusion in Brazil. Thus, a team was appointed to take care of that matter (GA-03; GA-10). At that point, some actors joined the Financial Inclusion Project (GA-03) and BCB forums on financial inclusion started taking place in 2009, trying to draw other actors' attention. The team of the Financial Inclusion Project consisted of employees from eight different BCB sectors. In order to guide the work done by the subgroup called Access Through Innovation Sub-Group (ATISG), the project incorporated activities related to what was being done by the Financial Inclusion Experts Group (G20), which is led by Brazil and Australia. ATISG addresses the relation between financial inclusion and technological development / institutional conditions, which are concerns of the Financial Inclusion Project.

In parallel with the project, the BCB started promoting its forums, inviting the actors (from the government, market, besides promoters, scholars and international actors) to take part in them (GA03). The $1^{\text {st }}$ Central Bank Forum on Financial Inclusion, that took place in 2009, was considered a milestone when it comes to articulation in support of financial inclusion in Brazil.

The BCB started gathering actors, providing conditions for making the access to the financial system something universal, thus, making the system itself more efficient (GA-03).

It is plausible to say that the event was a great watershed. From that point on, the network recognized that financial inclusion needed to make progress in Brazil (OPP). For that reason, they started combining efforts searching for solutions, after all, a great part of the population was financially excluded.

The first forum also encouraged debates on other topics, such as financial education and consumer protection. Due to its well-known ability to reunite several actors around a theme, the BCB became the focal agent of the network that was being built:

The Central Bank has always been willing to be the catalyst to gather all these actors in a way that none of them would lose their legal and regimental identity (GA-10).

The interviewee mentions that the $\mathrm{BCB}$ makes the continuity of policies an easy process for it has a solid structure, which is built exclusively by its employees. That may not be the case when it comes to other actors from the public sector.

Other interviewees' reports provide many reasons why the $\mathrm{BCB}$ was the focal agent of the whole network. The main reason had to do with its institutional role of regulating in the financial system. Its duty is ensuring a solid and effective financial system which must also be inclusive and competitive (MA-02 and GA-13). Besides, BCB's institutional agenda prioritizes financial inclusion. Therefore, it plays an important role of promoting and coordinating the process (MA-02). 


\subsection{Interessement}

Although the number of actors involved with microcredit and microfinances was considerable, the actors of this sector (regulators, operators and promoters) were not articulated towards the financial inclusion agenda-setting yet. A coordinated action to help organize the sector was necessary. The $1^{\text {st }}$ Central Bank Forum on Financial Inclusion was the kick-off event in the articulation process of the Brazilian Financial Inclusion Network. From that moment on, presentations and debates involving the actors created an environment of positive synergy. Articulation among them enabled making a diagnosis regarding financial inclusion in Brazil. That resulted in a database to support the next actions (GA-03). According to the interview, the BCB reshaped its strategic planning in February, 2020 , comprising the promotion of financial inclusion into its strategic goals to be achieved between 2010 and 2014. Due to that, financial inclusion gained strength as a theme to be incorporated by the agenda.

In April, 2010, the Department of Financial System Regulation (Denor) introduced an administrative component to address the aforementioned theme and other issues related to the financial system's socio-environmental responsibility. Thus, the Financial Inclusion Project was transferred from the Department of Financial System Organization (Deorf) to Denor, which, at that time, were both subordinate to the Directory of Financial System Norms and Organization (Dinor). Nowadays, the financial inclusion agenda is assigned to the Directory of Institutional Relationship and Citizenship.

With the support of a team devoted to the financial inclusion issue, the BCB started working on connecting with other governmental organs, market representatives and also promoters and scholars. They were convinced of the fact that financial exclusion was an economic and social problem and that, together, they could come up with solutions.

The public policy process and, mainly, the agenda-setting process are characterized by articulation among the actors. Since they have different ideas, principles and interests, they get connected to each other in different ways, which can be either for cooperating or competing. Regarding the agenda analyzed by this study, the interaction was basically cooperation-driven, based on communication, collaborative work and partnership. This combination gave rise to decisions made collectively. Cooperation among the actors helped them play their role in the agenda-setting process. "Bonds among the actors were aligned" (GA-07) as a public policy for common good.

The Central Bank of Brazil plays the role of both a promoter and a coordinator of the financial inclusion agenda in the country. Therefore, it established a strong connection with the other actors, aiming to exchange knowledge, identify problems and build up solutions collectively. In order to achieve a common goal, which was promoting appropriate financial inclusion in Brazil, the BCB created a system of alliances. The reports made by the interviewees (GA-03, GA-5, GA-06, GA-09, GA-10, GA-13, PS-02, MA-01, MA-02 and MA-03) show that the bank was the focal actor in the process, and that the purpose of its interaction with the other actors involved was solving problems successfully, meeting their expectations. 


\subsection{Enrolment}

Several actions were taken by the actors, who tried to play their roles according to their abilities in a cooperation process. The National Partnership for Financial Inclusion (PNIF), created in 2011, represents this scenario of collaborative acting among the actors engaged in the agenda, since it sought to connect knowledges and join forces. The PNIF is composed of a network of public and private actors, engaged in coordinated actions, aiming to promote adequate financial inclusion in Brazil (GA-03). It starts from the premise that the construction of the agenda demands communication, collaborative work and partnerships.

MA-01 states that the $\mathrm{BCB}$ was the main actor in the process, providing the bases which allowed the other actors to structure the agenda in question, discuss internally and contribute in a way that would add financial inclusion to the governmental agenda. Still referring to the PNIF, the Action Plan for Institutional Environment Strengthening was created in 2012. It encompassed 8 actions to be implemented between 2012 and 2014, focusing on the market, within 3 fronts: diagnosis, regulation/ education and transparency. Many actors engaged in these actions, which were all accomplished within the deadline (GA-03).

\subsection{Mobilization}

The financial inclusion agenda-setting is the result of a collective process and a balanced structure built up by the different actors in a cooperative movement. That resulted in progress of the agenda due to the

[...] creation of support policies from the government; [...] by 'government' I refer to an autarky involving the Central Bank, Ministries, as well as the National Department of Solidarity Economics (MA-01).

According to the interviewee, these actors' engagement was extremely important, for it resulted in a program to support and stimulate discussions on financial inclusion. The BCB is a significant actor when it comes to the Brazilian financial inclusion agenda because it has been working with actors from the public and private sectors since 1990, focusing on the articulation of knowledge and efforts to enhance financial inclusion in the country. The Brazilian Micro and Small Enterprises Support Service (Sebrae) has been partners with the BCB in the debates on financial inclusion in Brazil, as well as in the development of financial inclusion public policies.

This study presents four categories of actors (Box 3) that play relevant roles in the creation of the financial inclusion agenda, through associations, performing as actants, without the prevalence of a single actor. Instead, it is all about a network knocking down the assumption according to which the government is the absolute and central protagonist when it comes to solving public problems (Andrade, 2006).

Even though some actors performed in a more noticeable way than others, they all played the role of protagonists in the financial inclusion agenda-setting, according to their expertise within different publics (MA-02). At first, they acted in discussions that enabled a diagnosis regarding the related sectors. That was the base for their acting, so that, afterwards, they could seek solutions to expand 
financial inclusion by restructuring the regulatory mark, and also by implementing programs and actions in favor of financial inclusion.

\subsection{Discussion}

Figure 3 illustrates the process of social construction of the financial inclusion agenda, which was reproduced by this study through the four translation moments. That allowed us to define the identity of the actors and their interactions within the network that gave rise to such agenda.

\section{FIGURE 3 THE PROCESS OF FINANCIAL INCLUSION SOCIAL CONSTRUCTION THROUGH TRANSLATION}

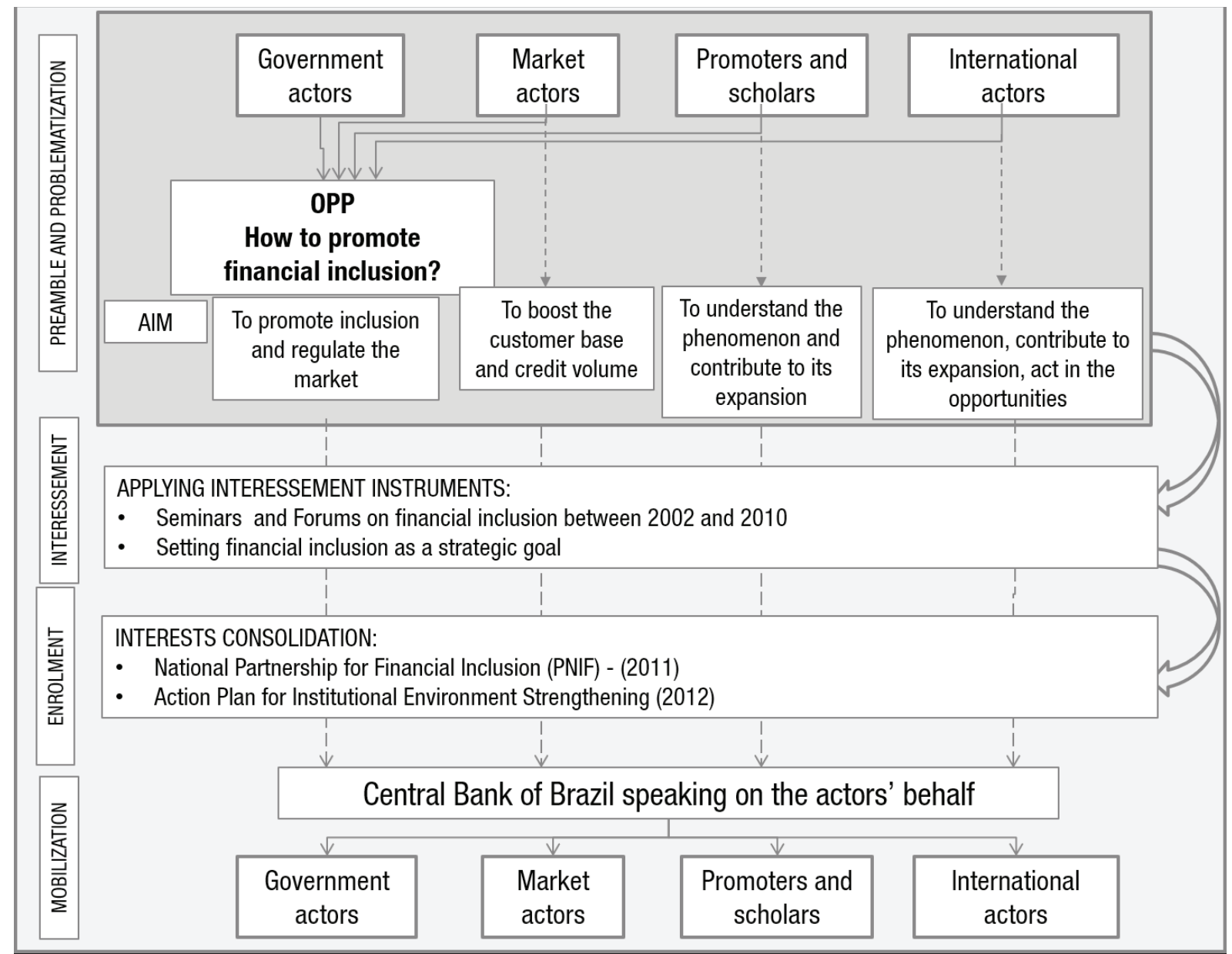

Source: Elaborated by the authors.

The first part of the figure (Preamble and Problematization) illustrates alliances among entities, defining a new identity to achieve what they wished. At the preamble phase, in 1990, with controlled inflation, financial inclusion gained relevance (GA-03). On the other hand, economic stabilization prompted the restructuring of the private financial system. In order to survive in a non-inflationary 
environment, the banking system (which was used to floating profits) went through mergers, incorporations and specializations focused on short-term sustainability. That ended up leading to the exclusion of low-income populations, as well as micro and small companies.

The big banks, as well as the government banks, disappeared, and a very large gap of classes not assisted by the traditional financial system began to emerge (GA-10).

As a reaction to this phenomenon, there were efforts to increase the supply of financial services to previously underserved populations using two vehicles, namely banking correspondents and credit cooperatives. Such measures contributed to increasing the capillarity of the financial system, collaborating, along with the other actions that were subsequently developed, for the expansion of financial inclusion in the country. From 2002 onwards, it is possible to identify the problematization phase, when BCB documents confirm its action to define the OPP in an agenda of financial inclusion. The actors' inter-definition, which is the first phase of problematization (Callon, 1986), could be noticed in the way the $\mathrm{BCB}$ assumes the objectives of the various actors in the various events it promotes. For example, in 2002, when promoting the second microcredit seminar, the bank stated that the main objective of the event was demonstrating that microcredit activity in Brazil can be a viable option for investors and other capital providers (Central Bank of Brazil [BCB], 2002). The actors' inter-definition, together with the definition of the OPP, continues at the problematization phase. In this sense, in 2005 and 2006, the BCB promoted international seminars, identifying international actors as funders. In the 2005 seminar, for example, the International Finance Corporation was identified as the financer of $80 \%$ of the capital for Microenterprise Credit Societies (SCMs) that offered microcredit at that time (Melo, 2005). Later, other organizations would contribute to defining the role of international actors, also as promoters and scholars (BCB, 2012). In turn, government actors were initially represented by the Ministry of Labor and Employment (MTE) and the BCB. The former, identified as an agent in search of development, took part in the $1^{\text {st }}$ Microcredit Seminar discussing the role of credit in solidarity economics. The latter, centralizing efforts, presented itself as an actor that aimed to "increase the supply of financial services to populations with a low Human Development Index (HDI) (2002)." By taking part in the events, the actors seemed to be confirming their objectives and accepting the OPP.

The second moment (interessement) implies testing the relationships among the entities. That includes confirming if they are integrated with the initial plan indeed, or if they refuse to define their identities, passing through the OPP. At this phase, the BCB sought to articulate all the members in the process, based on a collective definition of the agenda, by promoting the $1^{\text {st }}$ Forum on Financial Inclusion. The interessement phase also involves stopping the actors from being attracted by other entities that may divert them from their way towards the OPP. In other words, that means answering how to promote financial inclusion. At such phase, one of the elements that considerably contributed to preventing the actors from setting their own route was defining the strategic goals for financial inclusion, which was done by the BCB along with its partners. That joint work is represented by the dotted lines that connect the first translation moment to the second in Figure 3.

The enrolment phase involves negotiations. At such phase, the main demand is confirming the interests of all members involved in order to create an effective alliance for answering how to promote 
financial inclusion (OPP). The Action Plan for Strengthening Institutional Environment consolidated the result of several negotiations throughout time, such as the possibility of the microcredit segment capitalizing its offers and expanding its channels, thus, broadening its offers to the retail sector, tourism companies etc. At the same time, it boosted financial inclusion by facilitating access to its products. Another example is the regulatory mark for payment rules and institutions, a set of guidelines that allowed non-financial institutions to provide payment services. For that reason, many negotiations resulted in deals, as long as the actors involved contributed to financial inclusion (BCB, 2014).

Finally, at the mobilization phase, translation of the actors' goals was possible because they were represented by mediators. Government and market actors, as well as promoters, scholars and international actors are represented by entities described in Figure 3. Those citizens who were expected to be financially included are represented by the Ministry of Labor and Employment (MTE) and other governmental entities. As stated by Callon (1986), speaking on entities' behalf means, above all, silencing those on whose behalf we speak. Each single entity represents a group of actors, and the BCB is granted the right to speak on behalf of all groups through the instruments that are created. Inclusion is translated into graphs and guidelines in the National Partnership for Financial Inclusion, in a movement that is temporarily consolidated in a black box. However, they can be always questioned, since some conflicts remain as challenges that still must be overcome. The greatest of them refers to providing institutions that are not regulated by the $\mathrm{BCB}$ with access to funding. That also applies to the Credit Societies for Micro-entrepreneurs and Small Businesses (SCMEPPs), which, despite being regulated by the $\mathrm{BCB}$, are not allowed to raise funds.

Figure 4 summarizes the translation process of the financial inclusion agenda in Brazil.

\section{FIGURE 4 TRANSLATION OF THE BRAZILIAN FINANCIAL INCLUSION AGENDA}

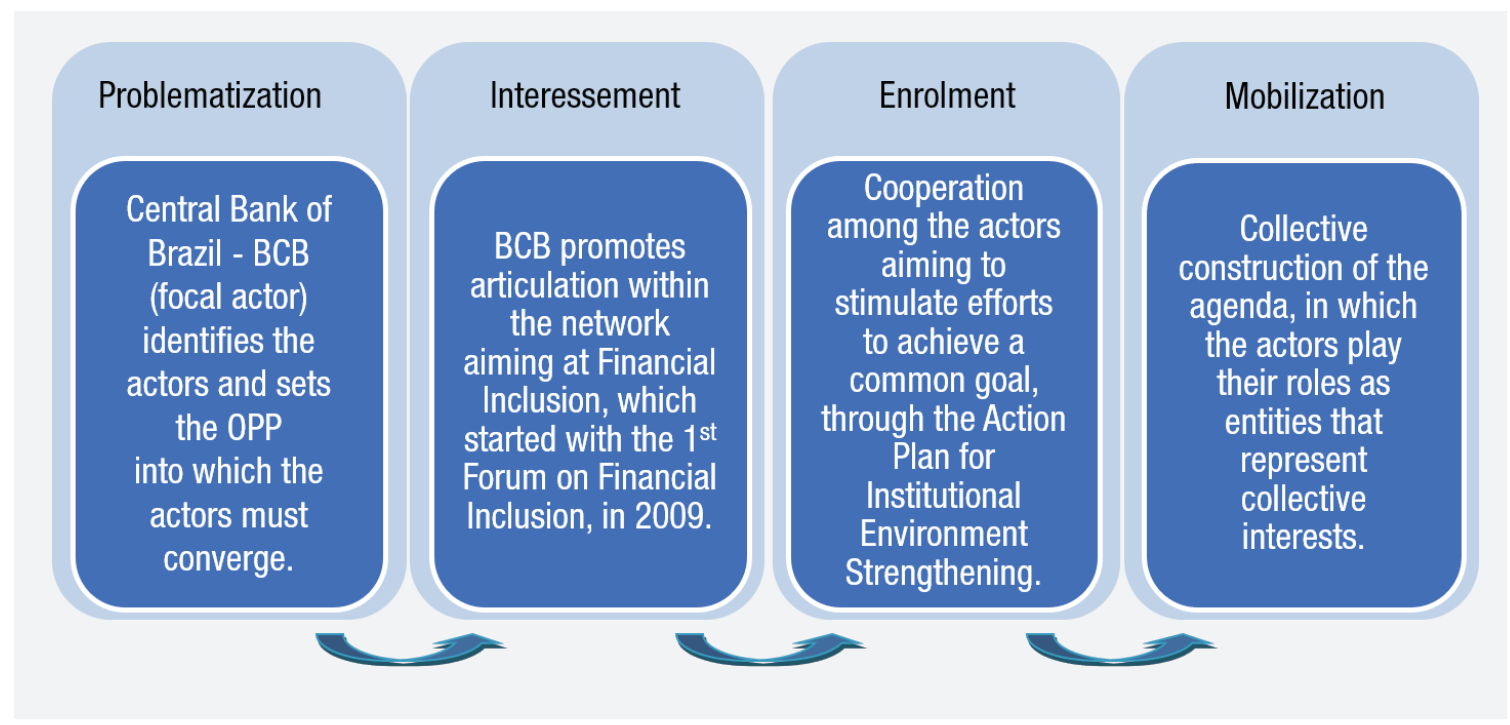

Source: Elaborated by the authors. 
During the path composed by the four moments, actors' identity, possibilities of interaction and rooms for maneuver were negotiated and delimited (Callon, 1986), which allowed us to identify how the actors connected to each other to achieve a common goal within the network. Translation took place when the actors went through these 4 moments and changed their preferences regarding the OPP, thus, closing the black box. During the process, the role played by the (human) actors was influenced by several political, economic and institutional factors (non-human elements). That highlighted the close relation between Brazil's financial inclusion agenda and the international context (GA-01, GA-03), bearing in mind that the country was represented by the BCB in partnerships with international organisms concerned with financial inclusion.

\section{FINAL CONSIDERATIONS}

This paper analyzes the actors' performance in the financial inclusion agenda-setting in Brazil, in light of the ANT, since we consider that this construction happens through a continuous process of associations among different actors. That means actors creating a relationship network by alternating roles, sometimes as subjects, and sometimes as objects (for instance, when the Superintendence of Private Insurance (Susep) sells products through several channels), but observing regulations established by the BCB. The same applies to the actors (government, market, promoters and scholars, international actors), who interact with each other and are influenced by several factors (national and international economic, political and institutional contexts).

The Actor-Network Theory was useful for understanding how the social relationship network was formed in favor of the expansion of financial inclusion in Brazil. Throughout the process, the BCB presents itself as a focal actor in the financial inclusion agenda-setting, seeking to articulate the relationship network, and striving to demonstrate, along the way, that it was "speaking" on behalf of all. That means favoring the expansion of financial inclusion in Brazil, translating everyone's interests. It was a collective construction process in which the actors sought to catalyze efforts to achieve a common goal. In such process, the BCB worked together with other government agencies, market entities, promoters and scholars, who were convinced that financial exclusion was an economic and social problem and that, together, they could come up with solutions. Moreover, financial inclusion represented a business opportunity for the leading banks. Our research shows that this conviction overcame conflicts that arose during the agendasetting process. In other words, financial inclusion managed to become socially legitimate, regardless of the theoretical controversies involving the theme (see Cull \& Morduch, 2017; Schicks, 2014). By understanding the actors' performance regarding the agenda in question, this study fulfilled the objectives it proposed, although there were some limitations. Even though we contacted a wide range of relevant actors, it was not possible to interview all of them, which resulted in lack of information on these actors' performance within the process, especially promoters' and scholars.' Despite these limitations, the research contributed to demonstrating the process of social construction the financial inclusion agenda in Brazil, thus, stimulating reflection upon the theme. Moreover, analyzing the actors' performance through the ANT perspective contributes to expanding the theory as a theoretical lens.

Further studies may include a comparison with other countries, as financial inclusion is a theme that has gained prominence worldwide (Demirgüç-Kunt et al., 2018). Future research can also evaluate the intersections between the financial inclusion agenda and other public policies for social inclusion. 


\section{REFERENCES}

Afonso, J. S., Morvant-Roux, S., \& Guérin, I. F. (2017). Doing good by doing well? Microfinance, self-regulation and borrowers' over-indebtedness in the Dominican Republic. Journal of International Development, 29(7), 919-935.

Alcadipani, R., \& Tureta, C. (2009). Teoria AtorRede e análise organizacional: contribuições e possibilidades de pesquisa no Brasil. Organizações \& Sociedade, 16(51), 647-664.

Altman, M. (2012). Implications of behavioural economics for financial literacy and public policy. The Journal of Socio-Economics, 41(5), 677-690.

Andrade, J. A. (2006). Redes de atores: uma nova forma de gestão das políticas públicas no Brasil? Gestão \& Regionalidade, 22(64), 52-66.

Atkinson, R., \& Flint, J. (2001). Accessing hidden and hard-to-reach populations: snowball research strategies. Social Research Update, 33.

Banco Central do Brasil. (2002). II Seminário Banco Central sobre Microcrédito, Belém, Pará. Retrieved from https://www.bcb.gov.br/htms/ eventos/SeminarioMicrocredito/index.htm

Banco Central do Brasil. (2012). Plano de Ação para Fortalecimento do Ambiente Institucional. Retrieved from https://www.bcb.gov.br/nor/relincfin/Plano_ de_Acao_PNIF.pdf

Banco Central do Brasil (2014). Parceria Nacional para Inclusão Financeira: Relatório do Plano de Ação para Fortalecimento do Ambiente Institucional 2012-2014. Retrieved from https://www.bcb.gov.br/ pec/appron/apres/Relat\%F3rio\%20PNIF\%20-\%20 Br.\%200462.pdf

Banerjee, A., Karlan, D, \& Zinman, J. (2015). Six randomized evaluations of microcredit: introduction and further steps. American Economic Journal: Applied Economics, 7(1), 1-21.

Bardin, L. (1979). Análise de conteúdo. Lisboa, Portugal: Ed. 70.

Baumgartner, F. R., \& Jones, B. D. (1993). Agendas and instability in American politics. Chicago, IL: University of Chicago Press.

Callon, M. (1986). Some elements of a sociology of translation: domestication of the scallops and the fishermen of St Brieuc Bay. In J. Law. Power, action and belief: a new sociology of knowledge? (pp. 196223). London, England: Routledge.

Camillis, P. K., Bussalar, C. Z., \& Antonello, C. S. (2016). A agência a partir da Teoria Ator-Rede: reflexões e contribuições para as pesquisas em administração. Organizações \& Sociedade, 23(76), 73-91.

Cobb, R. W., \& Elder, C. D. (1971). The politics of agenda-building: an alternative perspective for modern democratic theory. Journal of Politics, 33(4), 892-915.

Cooper, D. R., \& Schindler, P. S. (2003). Métodos de pesquisa em administração (7a ed.). Porto Alegre, RS: Bookman.

Cull, R., \& Morduch, J. (2017). Microfinance and economic development (Policy Research Working Paper No. 8252). Washington, DC: World Bank.

Custers, A. (2011). Furthering financial literacy: experimental evidence from a financial literacy program for microfinance clients in Bhopal, India (DESTIN Working Paper Series No. 11-113). London, England: London School of Economics.

Demirgüç-Kunt, A., Klapper, L., Singer, D., Ansar, S., \& Hess, J. (2018). The Global Findex Database 2017: measuring financial inclusion and the Fintech revolution. Washington, DC: World Bank.

Feltrim, L. E., Ventura, E. C. F., \& Dodl, A. V. B. (2009). Projeto Inclusão Financeira: perspectivas e desafios para a inclusão financeira no Brasil: visão de diferentes atores. Brasília, DF: Banco Central do Brasil.

Fornazin, M., \& Joia, L. A. (2015). Remontando a rede de atores na implantação de um sistema de informação em saúde. Revista de Administração de Empresas, 55(5), 527-538.

Godoy, A. S. (1995). Introdução à pesquisa qualitativa e suas possibilidades. Revista de Administração de Empresas, 35(2), 57-63.

Gonzalez, L., \& Moser, R. (2015). Green microfinance: the case of the Cresol System in Southern Brazil. Revista de Administração Pública, 49(4), 1039-1058.

Jerković, D., \& Petak, Z. (2017). Setting the policy agenda for combating the abuse of new psychoactive substances in the Republic of Croatia. Criminology \& Social Integration: Journal for Criminology, Penology and Behaviour Problems, 25(2), 47-62. 
Kingdon, J. W. (1995). Agendas, alternatives, and public policies (2nd ed.). New York, NY: Harper Collins.

Kunkel, F. I. R., Vieira, K. M., \& Potrich, A. C. G. (2015). Causas e consequências da dívida no cartão de crédito: uma análise multifatores. Revista de Administração (São Paulo), 50(2), 169-182.

Latour, B. (1999). On recalling ANT. In J. Law, \& J. Hassard. Actor Network Theory and after (pp. 15-26). Oxford, England: Blackwell.

Latour, B. (2001). A esperança de Pandora: ensaios sobre a realidade dos estudos científicos. Bauru, SP: Edusc.

Latour, B. (2012). Reagregando o social: uma introdução à teoria do ator-rede. Salvador, BA: Ed. UFBA.

Leandro, J., \& Gonzalez, L. (2018). Os desafios da educação financeira. GV-Executivo, 17(6), 12-15.

Luhmann, N., Bednarz, J., \& Baecker, D. (1996). Social systems. Palo Alto, CA: Stanford University Press.

Melo, C. H. T. X. (2005). Unibanco Microinvest. Anais do 40 Seminário Banco Central sobre Microfinanças, Salvador, BA. Retrieved from https://www.bcb.gov.br/acessoinformacao/ legado?url=https:\%2F\%2Fwww.bcb.gov.br\%2
Fpre\%2Fsemicrointer1\%2Fcurriculos\%2Fcarlos_ ximenes.asp\%3Fidpai\%3Dsemicrofin1sal

Minella, J. M., Bertosso, H., Pauli, J., \& Corte, V. F. D. (2017). A influência do materialismo, educação financeira e valor atribuído ao dinheiro na propensão ao endividamento de jovens. Revista Gestão \& Planejamento, 18(1), 182-201.

Pinto, C. C., \& Domenico, S. M. R. (2014). Teoria Ator-Rede em estudos organizacionais: encontrando caminhos via cartografia de controvérsias. In Anais do 80 Encontro de Estudos Organizacionais. Gramado, RS.

Ramos, E. A. (2009). Remontando a política pública: a evolução da política nacional de informática analisada pela ótica da Teoria do Ator-Rede (Doctoral Dissertation). Rio de Janeiro, RJ: Fundação Getulio Vargas.

Santos, R. P., \& Joia, L. A. (2018). Inclusão financeira de populações ribeirinhas: avaliação de impacto da Agência Barco. Revista de Administração Pública, 52(4), 650-675.

Schicks, J. (2014). Over-indebtedness in microfinance: an empirical analysis of related factors on the borrower level. World Development, 54(1), 301-324.

\section{Vilma Meurer Sela}

https://orcid.org/0000-0002-8594-9471

Doctoral degree in Public Administration and Government from Getulio Vargas Foundation (FGV EAESP); Professor at the Department of Administration - State University of Maringá (UEM).E-mail: vmsela@uem.br

\section{Lauro Gonzalez}

iD

https://orcid.org/0000-0001-9316-6525

Doctoral degree in Economics from the School of Business Administration - Getulio Vargas Foundation (FGV EAESP); Professor at the Department of Finances in the School of Business Administration - Getulio Vargas Foundation (FGV EAESP). E-mail: lauro.gonzalez@fgv.br

\section{Tania P. Christopoulos}

https://orcid.org/0000-0001-6310-3216

Doctoral degree in Business Administration from Getulio Vargas Foundation (FGV EAESP); Professor at the School of Arts, Sciences and Humanities - University of São Paulo (USP). E-mail: tchristop@gmail.com 